\title{
Nutritional Analysis of Few Selected Wild Edible Leafy Vegetables of Tribal of Jharkhand, India
}

\author{
Rekha Sinha* \\ Department of Home Science, Birsa Agricultural University, Ranchi-6, India \\ *Corresponding author
}

\section{A B S T R A C T}

Keywords

Wild edible plants, Tribal, Jharkhand, Proximate composition,

Mineral

Article Info

Accepted:

15 January 2018

Available Online:

10 February 2018
The nutritional potential of nine edible plants of tribal of Jharkhand was evaluated by determining proximate composition and micronutrient content. The result showed significance of wild leafy vegetable species as important source of nutrient for rural tribal. Protein content of different wild species ranged from $19.03 \pm 0.26$ to $31.16 \pm 0.20$ percent. The crude fiber content was found highest in Polygonum plebijum, while highest ash content was observed in Portulaca oleracea. Among micronutrient content, iron content ranged between $11.88 \pm$ to $397.66 \mathrm{mg} / 100 \mathrm{~g}$ with highest content in Trianthema monogyna. The calcium content ranged between $441.62 \pm 12.70$ to $4200 \pm 5.77 \mathrm{mg} / 100 \mathrm{~g}$, with highest content was observed in Sesbania grandiflora followed by cassia tora.The nutritional value of many wild species compared well with selected cultivated species namely amaranthus, spinach and fenugreek leaves in terms of protein, carbohydrate and fat and found superior in terms of crude fiber, mineral, calcium, iron and vitamin c content.

\section{Introduction}

Jharkhand is one of the eastern states, where bulk of tribal lives constituting about $28 \%$ of the tribal population. Majority of tribal population of the state lives in forest ecosystem and has its own socio-cultural pattern, traditions and typical food practices. They subsist on limited agriculture and local products of plant and animal origin. Vegetables eaten are mainly of leafy variety, which grow as wild weeds ${ }^{1}$. It has become their habit and till date, these edible plants are integral part of their diet. These are consumed more routinely as dominant source of leafy vegetables particularly in rainy and summer season, when the vegetables are in short supply; people collect various species of wild edible plants from their agricultural and non agricultural fields to supplement their staple food ${ }^{1}$. The range of these types of foods used by the tribal varies from locality to locality depending on the availability of resources. These edible wild foods play a significant role in the food and nutritional security of rural poor and tribal ${ }^{2,3}$. Nutritional value of these unconventional greens is precisely not known and need to be investigated to grade them according to their importance for wider use as they have remained confined due to lack of scientific knowledge and awareness. Nutritive value of commonly consumed leafy 
vegetables has been studied extensively but there is very loss information available on nutritive value of these unconventional leafy vegetables of regional importance ${ }^{4,5}$. Keeping this in view, an investigation was carried out to assess the nutrient composition of few selected species of wild leafy vegetables of tribal.

\section{Materials and Methods}

Collection of samples: Nine species of unconventional green leafy vegetables that are consumed widely in rural areas of Jharkhand were selected and collected from local market in a bulk. A general account of the selected vegetables is presented in table 1 . The samples of three popular cultivated vegetables namely Amaranthus gangeticus, fenugreek leaves (Trigonella foenum-graecum) and spinach (Spinacia oleracea) were also collected from local market for analysis and comparison.

Preparation of sample: leaves were sorted to remove foreign substances as well as thoroughly washed in water 2-3 times to remove the adhering dust and impurities and were dried in hot air oven at $60^{\circ} \mathrm{C}$ till constant weight was obtained. They were ground and kept in air tight container at $5^{0} \mathrm{C}$ for further chemical analysis.

\section{Chemical analysis}

Samples were analysed for moisture, crude protein, fat, crude fibre, and ash by standard methods $^{6}$. Carbohydrate content was determined by subtracting total sum of ash, crude fiber, crude fat and protein from 100.The samples were wet digested in a diacid mixture of nitric acid and perchloric acid $(5: 1, V / V)$. Calcium and iron in the digested sample was determined by the atomic absorption spectrophotometer ${ }^{7}$. Ascorbic acid of fresh sample was determined by 2,6 dichlorophenolinophenol titration method $^{8}$. All the analysis was done in triplicate.

\section{Statistical analysis}

The data were statistically analysed for analysis of variance to know the significant difference among various species ${ }^{9}$.

\section{Results and Discussion}

The macro and micronutrient content of selected vegetables are given in table 2 and table 3, respectively. An attempt was made to compare the nutritional content of wild species with three most popular commonly consumed leafy vegetables. Moisture content of wild leafy vegetables analysed ranged from $73.10 \pm 0.20$ to $92.43 \pm 0.27$ percent, while that of cultivated species ranged from $86.2 \pm 0.06$ to $92.1 \pm 0.20$ percent. Crude protein of selected nine wild species of leafy vegetables ranged from $19.03 \pm 0.26$ to $31.16 \pm 0.20$ percent. Crude protein content of Amaranthus gangeticus, Fenugreek leaves and spinach was recorded as $25.33 \pm 0.08,28 \pm 0.17$ and 22.560.1 \pm 7 percent, respectively. While analysing the fat content of selected nine wild leafy vegetables, the result showed that Marsilea minuta $(5.53 \pm 0.22 \%)$ had highest fat content followed by Sesbania grandiflora (5.23 $\pm 0.14 \%), \quad$ Polygonum plebijum (4.42 $\pm 0.14 \%)$, Trianthema monogyna $(4.13 \pm 0.18 \%)$ while least fat content was observed in Cassia tora $(0.91 \pm 0.05)$ followed by Celosia argentea $(1.21 \pm 0.072 \%)$, Alternanthera sessilis $(1.89 \pm 0.067 \%)$ and Bauhinia purpurea $(1.90 \pm 0.032 \%)$. Fat content of selected cultivated counterparts ranged from $2.26 \pm 0.145$ to $7.66 \pm 0.16$ percent. Ash content of selected nine wild species ranged from 7.59 to 31.82 percent. Crude fibre content was found to be maximum $(12.56 \pm 0.23 \%)$ in Polygonum plebijum followed by Celosia argentea $(10.08 \pm 0.09 \%)$, Portulaca oleracea (9.46 $\pm 0.15 \%)$, 
Trianthema monogyna (9.13 $\pm 0.18 \%)$, Bauhinia purpurea $(8.73 \pm 0.16 \%)$, Sesbania

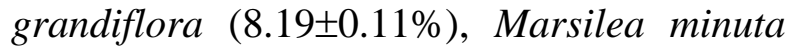
(7.33 $\pm 0.24 \%)$, Cassia toria $(7.25 \pm 0.32 \%)$, and Alternanthera sessilis $(6.99 \pm 0.25 \%)$. Carbohydrate content of selected wild vegetables were found in the range of $31.53 \pm 0.29$ (Portulaca oleracea) to $58.5 \pm 0.28$ percent (Cassia tora).

Micro-nutrient content of analysed vegetable species are given in table 3. Calcium content was in the range of $441.62 \pm 12.7$ to $4200 \pm 5.77$ $\mathrm{mg} / 100 \mathrm{~g}$; highest being in Sesbania grandiflora and lowest being in Bauhinia purpurea. Iron content were in the range of $15.16 \pm 0.44$ to $397.66 \pm 9.38 \mathrm{mg} / 100 \mathrm{~g}$. The Vitamin $\mathrm{C}$ content in edible parts of the vegetables is shown in table 3. High concentrations of Vitamin $\mathrm{C}$ were present ranging from 25.16 \pm 400 (Sesbania grandiflora) to $691.6 \pm 10.40 \mathrm{mg} / 100 \mathrm{~g}$ (Polygonum plebijum). The Vitamin C content of selected cultivated species were recorded between $28.50 \pm 28$ to $99 \pm 0.57$ $\mathrm{mg} / 100$.
Moisture content of each species were different from each other and it was highest in Portulaca oleracea followed by Trianthema monogyana and Celosia argentea, which were also comparable to selected commonly consumed cultivated species while others had comparatively lesser content. The values obtained for Sesbania grandiflora, Polygonum plebijum, Bauhinia purpurea and Trianthema monogyna are in close agreement with those reported by earlier investigator ${ }^{10}$.

Sesbania grandiflora followed by Bauhinia purpurea showed highest protein content among all nine species as well as the selected cultivated counterparts. Polygonum plebijum, Cassia tora and Trianthema monogyna exhibited relatively lesser protein content where as Marsilea minuta, Portulace oleracea Celosia argentea and Alternanthera sessilis exhibited comparable protein content as compared to spinach. Except Marsilea minuta, Sesbania grandiflora, Polygonum plebijum, Trianthema monogyna, other wild species were found to have lower fat content as compared to selected cultivated species.

Table.1 General account of wild edible leafy vegetables selected for nutrient analysis

\begin{tabular}{|l|l|l|l|l|}
\hline Sl.no. & \multicolumn{1}{|c|}{ Species } & \multicolumn{1}{|c|}{ Local Name } & Habit & Season of availability \\
\hline 1. & Sesbania grandiflora Pers. & Agasti & Tree & Summer \\
\hline 2. & Cassia tora Linn. & Chakor & Shurb & Rainy \\
\hline 3. & Polygonum plebijum R.Br. & Chimati sag & Herb & Winter \\
\hline 4. & Bauhinia purpurea Linn. & Koinar & Treo & Summer \\
\hline $\mathbf{5 .}$ & Marsilea minuta Linn. & Sunsunia & Herb & Rainy \\
\hline 6. & Portulaca oleracea Linn. & Golgala & Herb & Rainy \\
\hline 7. & Celosia argentea Linn. & Lahenga & Herb & Rainy \\
\hline 8. & Trianthema monogyna, Linn. & Khapra & Herb & Rainy \\
\hline 9. & Alternanthera sessilis Br. & Saronchi & Herb & Rainy \\
\hline
\end{tabular}


Table.2 Proximate composition of few selected wild leafy vegetables (g/100g, on dry wt. basis)

\begin{tabular}{|c|c|c|c|c|c|c|c|}
\hline Sl.no & Name & Moisture & Protein & Fat & Ash & Fibre & Carbohydrate \\
\hline 1. & Sesbania grandiflora & $73.10 \pm 0.20$ & $31.16 \pm 0.20$ & $5.23 \pm 0.14$ & $11.50 \pm 0.173$ & $8.19 \pm 0.11$ & $43.50 \pm 0.28$ \\
\hline 2. & Cassia tora & $77.62 \pm 0.47$ & $20.25 \pm 0.29$ & $0.91 \pm 0.05$ & $13.44 \pm 0.03$ & $7.25 \pm 0.32$ & $58.5 \pm 0.28$ \\
\hline 3. & Polygonum plebijum & $83.23 \pm 0.14$ & $19.03 \pm 0.26$ & $4.42 \pm 0.14$ & $23.33 \pm 0.45$ & $12.56 \pm 0.23$ & $44.30 \pm 0.35$ \\
\hline 4. & Bauhinia purpurea & $77.08 \pm 0.01$ & $29.40 \pm 0.05$ & $1.90 \pm 0.032$ & $7.59 \pm 0.043$ & $8.73 \pm 0.162$ & $47.43 \pm 0.29$ \\
\hline 5. & Marsilea minuta & $83.4 \pm 0.27$ & $24.90 \pm 0.88$ & $5.53 \pm 0.225$ & $10.43 \pm 0.13$ & $7.33 \pm 0.24$ & $57.50 \pm 0.28$ \\
\hline 6. & Portulaca oleracea & $92.43 \pm 0.27$ & $23.83 \pm 0.27$ & $3.05 \pm 0.130$ & $31.82 \pm 0.13$ & $9.46 \pm 0.154$ & $31.53 \pm 0.29$ \\
\hline 7. & Celosia argentea & $90.11 \pm 0.05$ & $22.67 \pm 0.52$ & $1.21 \pm 0.072$ & $20.82 \pm 0.17$ & $10.08 \pm 0.091$ & $45.50 \pm 0.25$ \\
\hline 8. & Trianthema monogyna & $91.20 \pm 0.20$ & $21.06 \pm 0.18$ & $4.133 \pm 0.186$ & $22.167 \pm 0.167$ & $9.13 \pm 0.186$ & $56.4 \pm 0.27$ \\
\hline 9. & Alternanthera sessilis & $80.06 \pm 0.14$ & $27.11 \pm 0.032$ & $1.89 \pm 0.067$ & $21.140 \pm 0.193$ & $6.99 \pm 0.253$ & $42.63 \pm 0.27$ \\
\hline 10. & Amaranthus gangeticus & $86.2 \pm 0.06$ & $25.33 \pm 0.088$ & $2.26 \pm 0.145$ & $16.90 \pm 0.208$ & $6.26 \pm 0.14$ & $49.41 \pm 0.30$ \\
\hline 11. & $\begin{array}{l}\text { Trigonella foenum- } \\
\text { graecum }\end{array}$ & $86.36 \pm 0.08$ & $28.76 \pm 0.17$ & $5.60 \pm 0.20$ & $9.10 \pm 0.55$ & $7.30 \pm 0.11$ & $49.30 \pm 0.35$ \\
\hline 12. & Spinach oleracea & $92.1 \pm 0.208$ & $22.56 \pm 0.176$ & $7.66 \pm 0.16$ & $19.23 \pm 0.14$ & $6.56 \pm 0.14$ & $43.70 \pm 0.15$ \\
\hline \multicolumn{2}{|r|}{ CD } & 0.61 & 1.01 & 0.42 & 0.69 & 0.56 & 0.54 \\
\hline
\end{tabular}

Values are mean \pm SE 
Table.3 Micronutrient content of few selected wild leafy vegetables (on dry weight basis)

\begin{tabular}{|c|c|c|c|c|}
\hline Sl.no & Name & Calcium (mg/100g) & $\begin{array}{c}\text { Iron } \\
(\mathrm{mg} / \mathbf{1 0 0 g})\end{array}$ & $\begin{array}{c}\text { Vitamin } C^{*} \\
(\mathrm{mg} / \mathbf{1 0 0 g})\end{array}$ \\
\hline 1. & Sesbania grandiflora & $4200 \pm 5.77$ & $15.167 \pm 0.441$ & $25.16 \pm 4.00$ \\
\hline 2. & Cassia tora & $3590.5 \pm 66.89$ & $45.83 \pm 0.381$ & $76.54 \pm 2.57$ \\
\hline 3. & Polygonum plebijum & $1153.33 \pm 14.33$ & $0.00 \pm 0.0$ & $259.33 \pm 1.86$ \\
\hline 4. & Bauhinia purpurea & $441.62 \pm 12.707$ & $59.127 \pm 0.33$ & $181.9 \pm 1.47$ \\
\hline 5. & Marsilea minuta & $501.0 \pm 0.06$ & $57.52 \pm 0.571$ & $69.06 \pm 0.009$ \\
\hline 6. & Portulaca oleracea & $1135.6 \pm 33.40$ & $115.87 \pm 2.996$ & $35.78 \pm 1.037$ \\
\hline 7. & Celosia argenta & 23.03 .06 & $155.71 \pm 2.996$ & $48.20 \pm 2.57$ \\
\hline 8. & Trianthema monogyna & $1030 \pm 1.54$ & $397.667 \pm 9.383$ & $70.16 \pm 0.16$ \\
\hline 9. & Alternanthera sessilis & $20.16 .03 \pm 19.45$ & $151.72 \pm 9.383$ & $691.6 \pm 10.400$ \\
\hline 10. & Amaranthus gangeticus & $2493.33 \pm 6.66$ & $21.76 \pm 0.145$ & $99.00 \pm 0.57$ \\
\hline 11. & $\begin{array}{l}\text { Trigonella foenum- } \\
\text { graecum }\end{array}$ & $3550.0 \pm 5.77$ & $12.63 \mathrm{~S} \pm 0.081$ & $52.13 \pm 0.24$ \\
\hline \multirow[t]{2}{*}{12.} & Spinach oleracea & $836.66 \pm 3.33$ & $13.00 \pm 0.15$ & $28.50 \pm 0.289$ \\
\hline & $\mathrm{CD}$ & 73.06 & 9.61 & 9.66 \\
\hline
\end{tabular}

Values are mean \pm SE

* Values are on fresh weight basis 
Though Marsilea minuta, Sesbania grandiflora, Polygonum plebijum andTrianthema monogyna exhibited higher fat content yet it was lower than Spinach. Among all selected twelve species highest fibre content was observed in Polygonum plebijum followed by Celosia argentea, Portulaca oleracea and Trianthema monogyna. As compared to selected cultivated species Protulaca oleracea followed by Polygonum plebijum, Trianthema monogyna and Alternanthera sessilis, Celosia argentea were found superior with respect to ash content while others except Bahuhinia purpurea were found comparable,. Wild species were found superior in terms of crude fibre content as compared to selected cultivated counterparts. As compared to cultivated species, higher carbohydrate content was found in Cassia tora, Marsilea minuta and Trianthema monogyna while polygonum pleijum, Bauhinia purpurea, Celosia argentea were found superior as compared to spinach.

Sesbania grandiflora exhibited highest calcium content among all tweleve species. Among cultivated species highest calcium content was observed in Fenugreek leaves and cassia tora recorded similar calcium content, while Polygonum plebijum, Portulaca oleracea, Celosia argentea, Trianthema monogyna, Alternanthera sessilis were found superior over spinach. Highest iron content was recorded in Trianthema monogyna followed by Celosia argentea, Alternanthera sessilis and Portulaca oleracea. All wild species were found superior in terms of iron content. Similar trend in the micronutrient composition of some uncommon greens has been reported by earlier workers ${ }^{11,5}$. Except Sesbania grandiflora, all selected unconventional leafy vegetables exhibited higher content of Vitamin C while Vitamin C content of Sesbania grandiflora was comparable to spinach. The finding of this study is close agreement with earlier worker $^{12}$, who also reported that nutritional value and mineral content of wild edible plants were richer than that of commercial vegetables.

In conclusion, the result highlighted significance of wild vegetable species as cheap sources of nutrient for rural tribal. The food value of many wild vegetables compared well with dominate popular leafy vegetables namely Amranthus, fenugreek leaves and spinach in terms of protein, Carbohydrate and fat. All wild species were found superior in respect of fibre. Mineral content was also found in much higher amount in five species where as rest species were found superior over fenugreek leaves. The comparison also revealed that majority of wild species was better in terms of calcium, iron and Vitamin C content.

\section{Acknowledgement}

The work was done as a part of departmental research and support provided by the university is duly acknowledged.

\section{References}

1. Sinha, R and Lakra, V., 2007. Edible weeds of tribals of Jharkhand, Orissa and West Bengal. Indian Journal of Traditional Knowledge 6: 217-222.

2. Mahapatra, AK., Mishra, S., Basak, CU and Pandan, PC., 2012 Nutrient analysis of selected wild edible fruits of Deciduous forest of India: An explorative study towards non conventional bio-nutrition. Advance Journal of Food Science and Technology 4: 15-21.

3. Sahu, RK., Kar, $M$ and Routray, R.,2013. DPPH free radical scavenging activityf some leafy vegetables used by tribals of Orissa, India. Journal of 
Medicinal Plant studies, 1: 21-27.

4. Nkafamiya, I., Osemeahon, SA., Modibbo, UU and Aminu, A.,2010.Nutritional status of nonconventional leafy vegetables, Ficus asperifolia and Ficus sycomorus. African Journal of Food Science. 4: 104108

5. Pattan, N and Usha, DC., 2014. Micronutrient and anti nutrient components of selected unconventional leafy vegetables in Bangalore city, India. Res, J. Recent. Sci. 3: 393-395

6. AOAC. 2010. Approved methods of Association of Official Analytical Chemists $14^{\text {th }}$ edition, Washington, DC.

7. Lindsay, W.L and Norwell, M.A., 1969. A new DPTA - TEA soil test for zinc and iron, Agron Abstract, 61: 84-85.

8. Ranganna, S., 1986. Handbook of analysis and quality control for fruit and vegetable products. $2^{\text {nd }}$ edition. Tata Mc Graw Hill Publishing Co. Ltd., New
Delhi. 1986, Pp. 105.

9. Panse, V.G and Sukhatme, P.V. 1961. Statistical methods for agricultural workers. $2^{\text {nd }}$ edn. Indian council of Agricultural Research, New Delhi.

10. Gopalan, C., Ramasastry, B., Manian, S.C. 2009. Nutritive Value of Indian Foods, National Institute of Nutrition, Indian Council of Medical Research, Hyderabad, India.

11. Thakur, S., Sudhanshu, K and Kumar, A., 2012. Potential of some wild leafy vegetables as natural source for supplementation of micronutrients in vegetarian diets of Santhal Paragna area of Jharkhand. Indian Journal of fundamental and applied life sciences 2(2012): 65-67.

12. Tapan, S., Pillai, B and Chaudhuri, K., 2014. Nutritive value and mineral composition of some wild edible plants from Meghalaya state in India. Advances in Biological Research 8: 116-122.

\section{How to cite this article:}

Rekha Sinha. 2018. Nutritional Analysis of Few Selected Wild Edible Leafy Vegetables of Tribal of Jharkhand, India. Int.J.Curr.Microbiol.App.Sci. 7(02): 1323-1329.

doi: https://doi.org/10.20546/ijcmas.2018.702.161 